\title{
KARAKTERISTIK MUTU DAN CITARASA COKELAT KAYA POLIFENOL
}

\author{
Characteristics of Quality and Flavor of Polyphenol-Rich Chocolate
}

\author{
Sitti Ramlah \\ Balai Besar Industri Hasil Perkebunan \\ JI. Prof.Dr.Abdurrahman Basalamah No.28 Makassar 90231 \\ Pos-el.st.ramlah.bbihp@gmail.com \\ (Artikel diterima 16 Maret 2016; direvisi 26 April 2016; disetujui 27 Juni 2016)
}

\begin{abstract}
Research of Flavor and Quality Characteristics of Rich Polyphenol Chocolate has been done. This research aims to understand the flavor and quality characteristics of polyphenol-rich chocolate, therefore can be used for functional food. Research method referred to Ramlah (2014), whereas cocoa beans roasting temperature was set on $40^{\circ} \mathrm{C}$ and $120^{\circ} \mathrm{C}$ and re-formulated without soy milk addition. Testing parameters are moisture content, protein as SNI 2323-2008 procedure, fat content as SNI 37492009 procedure, flavor test and polyphenol content using spectrophotometer analyzed in Indonesia Coffee and Cocoa Research Institute, Jember. Results of this study concluded that chocolate made from fermented cocoa beans roasted at $40^{\circ} \mathrm{C}$ has the quality characteristics of the water content of $2.03 \%$; protein content of $11.15 \%$; fat content of $48.67 \%$ and polyphenol content of $5.36 \%$. Chocolate prepared from fermented cocoa beans roasted at $120^{\circ} \mathrm{C}$ has the quality characteristics of water content of $1.43 \%$; protein content of $8.84 \%$; fat content of $53.39 \%$ and polyphenol content of $4.83 \%$. In terms of flavor, overall panelists' acceptance to chocolate F1 is to have good flavor and aroma and tend to be acidic, whereas chocolate $F 2$ has very good flavor and aroma.
\end{abstract}

Kata Kunci characteristics of quality, flavor, roasting, chocolate, Polyphenol.

Abstrak. Penelitian Karakteristik Mutu Dan Citarasa Cokelat Kaya Polifenol telah dilakukan. Penelitian ini bertujuan bertujuan untuk mengetahui sejauhmana karakteristik mutu dan citarasa cokelat yang mengandung polifenol yang tinggi, sehingga diharapkan dapat dimanfaatkan sebagai makanan kesehatan. Metode penelitian mengacu pada penelitian Ramlah (2014) dengan suhu penyangraian biji kakao $40^{\circ} \mathrm{C}$ dan $120^{\circ} \mathrm{C}$, yang diformulasikan ulang tanpa penambahan susu kedelei. Parameter uji yang digunakankadar air,protein mengacu pada SNI 2323-2008, kadar lemak mengacu pada SNI 3749-2009, Uji Citarasa dan uji kadar polifenol dengan Spektrofotometer diuji pada lab.Puslitkoka Jember. Dari hasil penelitian dapat disimpulkan bahwa cokelat yang diolah dari biji kakao fermentasi yang disangrai dengan suhu 40 ${ }^{\circ} \mathrm{C}$ mempunyai karakteristik mutu; kadar air air 2,03\%, kadar protein 11,15\%, kadar lemak 48,67 \% serta mengandung polifenol 5,36 \% Cokelat yang diolah dari biji kakao fermentasi yang disangrai dengan suhu $120^{\circ} \mathrm{C}$ mempu nyai karakteristik mutu; kadar air $1,43 \%$, kadar protein 8,84\%, kadar lemak 53,39\% serta mengandung polifenol 4, $83 \%$.Dari segi citarasa secara keseluruhan diperoleh bahwa penerimaan panelis secara umum terhadap cokelat $F 1$ adalah mempunyai citarasa aroma dan flavor yang bagus (good) dan cenderung asam, sedangkan F2 mempunyai citarasa aroma dan flavor yang sangat bagus (very good).

Kata Kunci : Karakteristik Mutu, Citarasa, Penyangraian, Cokelat, Polifenol.

\section{PENDAHULUAN}

Biji kakao mengandung lemak (cocoa butter) antara $50-70 \%$, yang terdiri dari $34 \%$ asam stearat (18:0); $34 \%$ asam oleat (18:1); $25 \%$ asam palmitat (16:0); dan $2 \%$ asam linoleat (18:3) (Ross, 2001).

Kakao merupakan sumber polifenol yang bermanfaat bagi kesehatan manusia. Beberapa manfaat polifenol yang telah diteliti adalah berfungsi sebagai antioksidan dalam menangkal radikal bebas, anti inflamasi yaitu membantu mengurangi dampak samping reaksi peradangan, dan antiproliferasi khususnya terhadap sel kanker yang menunjukkan kemampuan polifenol dalam menekan proliferasi (perbanyakan) sel kanker (Anonim, 2012).

Komposisi polifenol dalam biji kakao kering $\pm 15 \%$, yang didominasi oleh epikatekin dan katekin. Dengan komposisi tersebut, yaitu adanya lemak kakao dan polifenol membuat cocoa dan cokelat sebagai makanan fungsional (Ross , 2001) 
Cocoa dan cokelat bukan hanya terdiri dari lemak tetapi juga mengandung karbohidrat dan protein, serta mineral mineral seperti: zat besi, fosfor, kalium, krom, magnesium, mangan, dan lain - lain. Cokelat juga menandung teobromin dan kafein, merupakan senyawa - senyawa yang bekerja di pusat saraf yang dalam jumlah tertentu dapat mengangkat mood (Afriansyah, 2006). Pasta cokelat mengandung alkaloid yaitu teobromin $1-2 \%$ dan kafein $<1 \%$.Teobromin merupakan diuretic ringan, stimulant jantung, dan dapat digunakan untuk mengobati tekanan darah (Star, 2006).

Cokelat merupakan salah satu produk olahan kakao yang banyak digemari masyarakat karena mempunyai citarasa yang khas. Namun cokelat yang beredar dipasaran umumnya mengandung kalori yang tinggi, karena selain biji kakao yang digunakan sebagai bahan baku pada proses pembuatan cokelat juga ditambahkan gula , susu dan bahan tambahan lainnya, sehingga untuk masyarakat yang mempunyai masalah /kelebihan berat badan dan penyakit tertentu tak dapat menghindari untuk mengkonsumsi produk cokelat ini.

Cokelat merupakan salah satu produk kakao yang paling istimewa dibanding produk-produk lainnya.Cokelat memiliki tiga sifat utama yang membedakannya dari produk-produk lai, yaitu kekhasan citarasa, tekstur, dan warnanya. Padatan cokelat berperan sebagai pemberi citarasa dan warna, sedangkan lemak dalam cokelat berperan dalam mengendalikan tekstur produk.Kompleksitas citarasa cokelat terdiri dai ratusan komponen yang yang sangat spesifik dan tidak bisa digantikan oleh sumber lain. Rasa khas cokelat tidak lain adalah suatu kombinasi yang seimbang dari rasa dasar pahit, asam, dan manis yang tersusun dari komponen-komponen unik dalam cokelat.(Misnawi dan Jinap, 2008 ).

Citarasa adalah merupakan salah satu faktor penting pada produk cokelat. Citarasa cokelat sangat ditentukan oleh faktor fermentasi dan pengeringan biji kakao. Selama fermentasi akan terbentuk senyawa precursor citarasa, memperbaiki warna, mengurangi rasa sepat dan pahit. Senyawa precursor tersebut akan mengembang pada saat penyangraian. Selama penyangraian terjadi reaksi-reaksi kimia pembentuk aroma khas cokelat dari calon pembentuknya melalui reaksi Maillard.

Kompleksitas citarasa cokelat terdiri dari ratusan komponen yang sangat spesifik dan tidak bisa digantikan oleh sumber lain. Rasa khas coklet tidak lain adalah suatu kombinasi yang seimbang dari rasa dasar pahit, asam, dan manis yang tersusun dari komponen-komponen unik dalam cokelat (Misnawi dan Jinap, 2008.).

Untuk mendapatkan cokelat yang mempunyai rasa khas cokelat yang tinggi serta warna dan aroma yang bagus maka bahan baku yang digunakan pada pembuatan cokelat adalah biji kakao fermentasi . Namun dari segi kandungan fungsionalnya untuk kesehatan seperti polyfenol akan berkurang selama proses fermentasi. Untuk itu perlu dilakukan penelitian yang menghasilkan produk cokelat kaya polifenol dan dengan rasa, aroma yang disukai konsumen.

Hasil penelitian Suprapti et al (2011) menunjukkan bahwa penyangraian sangat berpengaruh terhadap kandungan polifenol pasta kakao non fermentasi. Semakin tinggi suhu penyangraian semakin rendah kadar polifenol pasta kakao yang dihasilkan.

Pembuatan makanan kesehatan dari biji kakao non fermentasi menghasilkan pasta kakao dengan kandungan polifenol yang tinggi yaitu antara $7,29-11,87 \%$, namun dari citarasa sangat tidak disukai oleh konsumen (Suprapti et al.,2011).

Hasil penelitian Ramlah (2014), menunjukkan bahwa suhu penyangraian pada biji kakao fermentasi mempengaruhi polifenol dan citarasa cokelat yang dihasilkan. Kadar polifenol cokelat dari biji kakao yang disangrai dengan $120{ }^{\circ} \mathrm{C}$ mengandung polifenol sebesar 3,76 \% sedangkan cokelat dari biji kakao yang disangrai dengan suhu $40{ }^{\circ} \mathrm{C}$ sebesar $4,95 \%$.

Pada penelitian Ramlah (2014), pembuatan cokelat menggunakan bahan subtitusi susu kedelei, sedangkan untuk penelitian ini tidak menggunakan susu kedelei sebagai bahan baku pembuatan cokelat. 
Cokelat dengan kandungan kakao (biji cokelat) lebih dari $70 \%$ (dark chocolate) juga memiliki manfaat untuk kesehatan, karena cokelat ini kaya akan kandungan antioksidan yaitu fenol dan flavonoid. Dengan adanya antioksidan, akan mampu untuk menangkal radikal bebas dalam tubuh. Besarnya kandungan antioksidan ini bahkan 3 kali lebih banyak dari teh hijau, minuman yang selama ini sering dianggap sebagai sumber antioksidan (Khomsan, 2003).

Dengan adanya antioksidan, membuat cokelat menjadi salah satu minuman atau makanan kesehatan.Fenol sebagai antioksidan mampu mengurangi kolesterol pada darah sehingga dapat mengurangi resiko terkena serangan jantung, juga berguna untuk mencegah timbulnya kanker dalam tubuh, mencegah terjadinya stroke dan darah tinggi.Selain itu kandungan lemak pada cokelat memiliki kualitas tinggi, terbukti bebas kolesterol dan tidak menyumbat pembuluh darah (Khomsan, 2003).

Pada penelitian ini pembuatan cokelat menggunakan bahan baku biji kakao fermentasi, tanpa penambahan susu kedelei atau susu hewan lainnya.

Penelitian ini bertujuan untuk mengetahui sejauhmana karakteristik mutu dan citarasa cokelat yang mengandung polifenol yang tinggi, sehingga diharapkan dapat dimanfaatkan sebagai makanan kesehatan.

\section{METODOLOGI}

\section{Bahan dan Alat Penelitian}

Bahan baku : biji kakao fermentasi (Theobroma cacao L), lemak kakao, gula rendah kalori, lesithin, vanili.

Bahan kimia : petroleum eter, aquabides, hexan, $\mathrm{HCl} 6 \mathrm{~N}, \mathrm{NaOH} 6 \mathrm{~N}, \mathrm{~Pb}$ Asetat $40 \%$, Asam oksalat $15 \%$

Alat penelitian yang digunakan adalah alat roasting, alat winnowing, alat conching universal, alat tempering, cetakan.

Sedangkan alat untuk analisis cokelat: HPLC, spektrofotometri, AAS, soxhlet, oven listrik dan eksikator.

\section{Metode Penelitian}

Penelitian inidilakukan mengacu pada penelitian Ramlah (2014), yang diformulasikan ulang menjadi 2 formula. Pada penelitian Ramlah (2014) formula yang digunakan menggunakan susu kedelei., sedangkan pada penelitian ini cokelat yang dibuat adalah dark cokelat dari biji fermentasi tanpa campuran kedelei. Produk cokelat yang diperoleh diuji sesuai parameter uji yang digunakan.

Prosedur penelitian dapat dilihat pada Gambar 1.

Adapun formula cokelat yang digunakan pada penelitian mengacu pada penelitian Ramlah (2014) dimodifikasi tanpa penambahan susu kedelei . Rincian lengkap dari setiap formula yang digunakan pada penelitian ini dapat dilihat pada Tabel 1.

\section{Tabel 1. Komposisi Formula cokelat} kaya polifenol

\begin{tabular}{clcc}
\hline No. & \multicolumn{1}{c}{ BAHAN BAKU } & F1 & F2 \\
\hline 1. & Nib Kakao F1 $(40 \circ \mathrm{OC})$ & $84,5 \%$ & - \\
2. & Nib Kakao F2 $(120 \circ \mathrm{OC})$ & - & $84,5 \%$ \\
3. & Gula Rendah Kalori & $10 \%$ & $10 \%$ \\
4. & Lemak Kakao & $5 \%$ & $5 \%$ \\
6. & Lesitin & 0,35 & $0,35 \%$ \\
7. & Vanili & 0,1 & $0,1 \%$ \\
8. & Garam & $0,05 \%$ & $0,05 \%$ \\
\hline
\end{tabular}

\section{Parameter Uji dan Metode Analisis}

Pengujian kadar air, karbohidrat mengacu pada SNI 2323-2008, kadar lemak mengacu pada SNI 3749-2009, Uji Citarasa dan uji kadar polifenol dengan Spektrofotometer diuji pada lab.Puslitkoka Jember. 


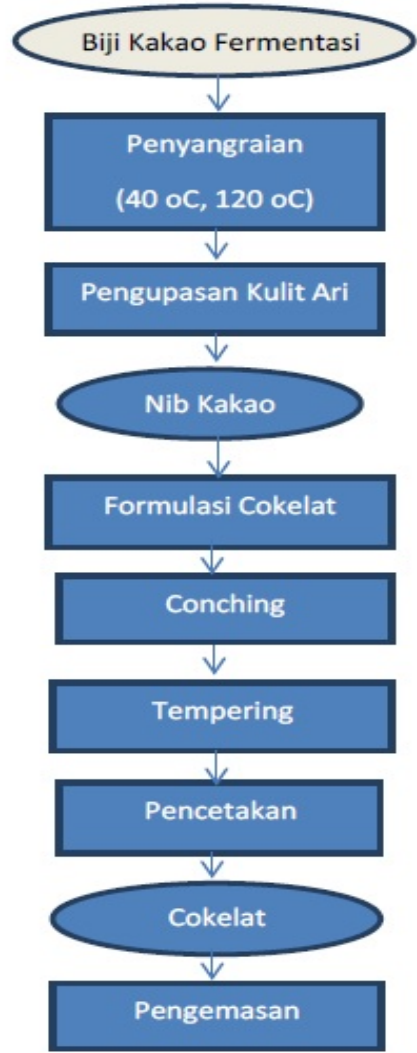

Gambar 1. Diagram Alir Prosedur Penelitian

\section{HASIL DAN PEMBAHASAN}

Tabel.2. Hasil Analisa Mutu Cokelat Kaya Polifenol

\begin{tabular}{|l|l|l|l|}
\hline No. & Parameter Uji & F1 (\%) & F2 \\
\hline 1. & Kadar Air & 2,03 & 1,43 \\
\hline 2. & Kadar Protein & 11,15 & 8,84 \\
\hline 3. & Kadar Lemak & 48,67 & 53,39 \\
\hline 4. & Kadar Polifenol & 5,36 & 4,83 \\
\hline
\end{tabular}

\section{Kadar Air}

Kadar air merupakan faktor yang sangat penting terhadap mutu suatu produk. Kandungan air sangat berpengaruh terhadap konsistensi bahan pangan. Pada umumnya keawetan bahan pangan mempunyai hubungan erat dengan kadar air yang dikandungnya (Winarno, 1980).

Hasil pengujian kadar air cokelat berkisar $1,43 \%$ hingga $2,03 \quad \%$ (Tabel 2). Kadar air cokelat F1 cenderung lebih tinggi dari cokelat F2. Hal ini diduga disebabkan cokelat F1 menggunakan bahan baku nib kakao dengan suhu penyangraian yang lebih rendah $\left(40^{\circ} \mathrm{C}\right)$ di banding cokelat
F2 $\left(120{ }^{\circ} \mathrm{C}\right)$. Menurut Winarno (1992), semakin tinggi suhu yang diberikan kepada suatu bahan, maka molekul-molekul air yang ada di dalam bahan tersebut akan semakin bergerak cepat dan melepaskan diri dari permukaan bahan dan menjadi gas.

\section{Kadar Protein}

Dari Tabel 2 juga dapat dilihat, bahwa cokelat F1 mengandung kadar protein yang lebih tinggi $(11,15 \%)$ dibanding dengan kadar protein dari cokelat F2 (8,84 \%). Tingginya kandungan protein pada cokelat F1 diduga disebabkan penggunaan nib kakao suhu penyangraian $40{ }^{\circ} \mathrm{C}$ ( suhu rendah). Pada saat proses penyangraian terjadi reaksi gula dengan asam amino (Beckett, 2000), dan selama penyangraian terjadi penurunan asam amino. (Brito et al, 2004). Menurut Suprapti (2013), semakin rendah suhu dan makin cepat waktu penyangraian, maka kadar asam amino semakin tinggi. Asam amino dalam pasta kakao berkisar 10,234 \% - $11,978 \%$.

Pada dasarnya protein dibentuk oleh satuan-satuan asam amino yang membentuk "polimer" sehingga merupakan senyawa yang panjang.Kadar protein di dalam suatu produk pangan menentukan mutu produk itu sendiri.Protein dapat mengalami kerusakan oleh pengaruh panas, reaksi kimia dan asam atau basa, goncangan dan sebab lainnya (Winarno, 1980).

Biji kakao kaya akan protein antara $10-15 \%$. Pada saat fermentasi protein akan berkurang, demikian juga pada saat pemeraman buah (Afoakwa et al, 2011). Protein biji kakao mempunyai 4 tipe yaitu; albumin, globulin, prolanin, dan glutein. Albumin dan globulin merupakan bagian terbesar dan diketahui $52 \%$ dari $43 \%$ dari total protein. Biji kakao juga kaya akan peptide dan asam amino, ini merupakan precursor aroma cokelat (Jalil et al, 2008).

Fermentasi pada pengolahan biji kakao menghendaki terjadinya perubahan kimiawi dalam biji.Perubahan kimiawi tersebut dikehendaki selain agar dapat terbentuk komponen precursor aroma dan memperbaiki citarasa juga untuk menghasilkan warna yang menarik.Senyawa pembentuk citarasa 
pada cokelat adalah polifenol, theobromin, dan asam-asam organik. Sedangkan komponen precursor aroma diantaranya asam amino dan gula reduksi, terbentuk dari hasil hidrolisis protein dan sukrosa biji kakao (Jinap et al, 2010).

\section{Kadar Lemak}

Hasil uji terhadap kadar lemak Cokelat yang dihasilkan berkisar 48,67\% hingga53,39 $\%$ (Tabel 2). Dari Tabel 2, menunjukkan bahwa kadar lemak Cokelat F2 lebih tinggi dari cokelat F1 . Hal ini disebabkan kadar Lemak Nib kakao pada cokelat F2 yang digunakan adalah Nib kakao dengan suhu penyangraian $120^{\circ} \mathrm{C}$. Suhu penyangraian yang lebih tinggi akan menguapkan kadar air yang terkandung dalam biji kakao sehingga akan menyebabkan konsentrasi kandungan lemak cenderung lebih tinggi.

Kisaran kadar lemak kakao Indonesia adalah antara 49 - 52 \% (Mulato et al, 2005). Lemak kakao merupakan campuran trigliserida , yaitu senyawa gliserol dan tiga asam lemak. Komposisi asam lemak kakao sangat berpengaruh pada titik leleh dan tingkat kekerasan lemak kakao.Titik leleh lemak kakao yang baik untuk makanan cokelat adalah mendekati suhu badan manusia dengan tingkat kekerasan minimum pada suhu kamar (Minifie, 1999).

\section{Kadar Polifenol}

Hasil pengujian polifenol pada Tabel 2 diperoleh bahwa kadar polifenol tertinggi diperoleh dari cokelat F1, menyusul cokelat F2. Tingginya kandungan polifenol cokelat F1 diduga disebabkan cokelat F1 menggunakan nib kakao suhu penyangraian $40{ }^{\circ} \mathrm{C}$. Sedangkan untuk cokelat F2, kadar polifenolnya lebih kecil dari cokelat F1, karena formula Cokelat F2 menggunakan nib kakao dengan suhu penyangraian 120 ${ }^{\circ} \mathrm{C}$.

Menurut Suprapti (2011), semakin rendah suhu penyangraian dan makin cepat waktu penyangraian maka kandungan polifenol semakin tinggi. Bernaert (2007), menyatakan bahwa penyangraian dapat menurunkan kadar polifenol sampai $20 \%$.
Sedangkan pada pembuatan pasta cokelat pada suhu yang tinggi dapat menurunkan kadar polifenol sebesar $10 \%$. Selanjutnya Thomas et al (2007), menyatakan bahwa penyangraian biji dengan suhu yang tinggi dan waktu yang lama akan mengurangi polifenol karena terjadi degradasi yaitu oksidasi enzimatis maupun non enzimatis.

\section{Uji Citarasa}

\section{Aroma dan Flavor}

Hasil uji citarasa cokelat terhadap aroma dan flavor diperoleh bahwa Cokelat F2 mempunyai Chocolate aroma $(7,30)$ dan Intensity of aroma $(7,10)$ yang berarti " strong”, sedangkan Cokelat F1 mempunyai nilai 6,90 dan Intensity of aroma 6,60 yang berarti "Moderately Strong" bahkan mendekati "Strongl' . Tingginya aroma cokelat pada cokelat F2 disebabkan suhu penyangraian yang digunakan terhadap biji kakao yang digunakan yaitu suhu 120 ${ }^{\circ} \mathrm{C}$, dibanding cokelat $\mathrm{F} 1$ yang disangrai dengan suhu $40^{\circ} \mathrm{C}$. Menurut Klahors,( 2005) saat penyangraian dengan suhu tinggi akan terjadi reaksi oksidasi flavonoid yang akan membantu pembentukan flavor, dan menyebabkan rasa khas cokelat yang akan semakin tajam.

Penyangraian biji kakao dengan suhu tinggi $\left(120^{\circ} \mathrm{C}\right)$ akan menyebabkan terjadi penguapan asam-asam dibanding dengan menggunakan suhu rendah $\left(40^{\circ} \mathrm{C}\right)$ sehingga didapatkan intensitas aroma dan flavor cokelat yang lebih tinggi.

Penyangraian bertujuan untuk membentuk aroma dan citarasakhas cokelat dari biji kakao dengan perlakuan panas (Mulato et al, 2005). Biji kakao yang telah difermentasi dan dikeringkan dengan baik mengandung cukup banyak senyawa calon pembentuk citarasa dan aroma khas cokelat antara lain asam amino dan gula reduksi. Jika dipanaskan pada suhu dan waktu yang cukup, keduanya akan bereaksi membentuk senyawa Maillard (reaksi pembentukan rasa dan aroma).

Kualitas citarasa cokelat sangat ditentukan oleh kondisi penyangraian, khususnya waktu dan suhu sangria. 
Senyawa pembentuk aroma khas cokelat seperti pirazin, karbonil dan ester meningkat selama penyangraian (Misnawi dan Jinap, 2008).

Tabel 3. Hasil Analisis ( Skor Citarasa) Citarasa Cokelat (Panelis terlatih)

\begin{tabular}{llll}
\hline No. & Karakteristik & F 1 & F 2 \\
\hline 1. & Chocolate aroma & 6,90 & 7,30 \\
2.. & Intensity of aroma & 6,60 & 7,10 \\
3. & Chocolate Flavour & 6,30 & 6,75 \\
4, & Intensity of flavor & 6,00 & 7,00 \\
5. & Acidity & 5,70 & 6,15 \\
6. & Bitterness & 5,75 & 6,00 \\
7. & Astringency & 5,40 & 4,80 \\
8. & Preference & 6,00 & 6,55 \\
9. & Texture (Kehalusan) & 7,80 & 7,70 \\
10. & Caramelly & 5,95 & 6,25 \\
11. & Creamy & 6,35 & 6,70 \\
12. & Sweetness & 6,20 & 6,95 \\
& Comments & Too acid, Good & Very Good Aroma \\
& & Aroma dan Flavor & dan Flavor \\
\hline
\end{tabular}

Keterangan: Notation for taste and Intensity; 0 = Nil ; 1-2 = Weak ; 3-4 =Moderately weak; 5-6 =Moderately Strong; 7-8 = Strong; 9-10 = Very Strong.

Notation for Preference and Quality ; $0=$ Inconsumable ; $1-2=$ Very bad ; 3-4 = Bad; $5-6=$ Neytral ; 7-8 $=$ Good, 9-10 $=$ Exell

Komponen-komponen aroma cokelat terbentuk selama penyangraian biji kakao dari calon-calon pembentuk citarasa seperti asam amino, peptide, gula pereduksi dan kuinon. Senyawa-senyawa tersebut terbentuk selama proses penyiapan biji, khususnya selama proses fermentasi dan pengeringan. Selama proses penyangraian senyawa calon pembentuk citarasa bereaksi satu sama lain melalui reaksi Maillard menhasilkan komponen-komponen yang mudah menguap dan beraroma khas cokelat. Komponen-komponen tersebut termasuk dalam golongan alcohol, eter, furan, tiazol, piron, asam, ester, aldehida, imin, amin, oksazol, pirazin, dan pirol.Hasil penelitian Misnawi dan Jinap (2008), sebanyak 10 95 macam pirazin ditemukan dalam aroma cokelat.Konsentrasi pirazin-pirazin sangat ditentukan oleh waktu dan suhu udara dalam penyangraian biji kakao. Meski demikian hasil penelitian Jinap et al .1998 dan Misnawi et al. 2004, menunjukkan bahwa hanya 2,5 - dimetil-, 2,3-dimetil, 2,3,5-trimetil-, dan 2,3,5,6-tetrametilpirazine yang dijumpai dalam konsentrasi tinggi, yakni dalam hasil sangrai biji kakao fermentasi .

Senyawa yang dianggap besar konstribusinya terhadap aroma dan flavor dalam kakao adalah pirazin, karena sifatnya non volatile (Jinap et al, 1994) dan menurut Reineccius et al (1972), bahwa senyawa pirazin dengan rumus kimianya 2,5-dimetil-2,3,5-trumetil-danand 2, 3, 5, 6-tetrametilpirazin adalah senyawa yang memberikan kekhasan cokelat.

\section{Citarasa Caramelly}

Hasil uji citarasa cokelat terhadap citarasa caramelly cokelat diperoleh cokelat F1 dengan nilai 5,95 dan cokelat 6,25 yang berarti sama-sam dalam kategori Moderately Strong (agak kuat).Namun dari segi nilai hasil uji dapat dilihat bahwa cokelat F2 mempunyai nilai citarasa caramelly lebih tinggi dibanding dengan cokelat F2. Hal ini diduga disebabkan oleh pengaruh suhu penyangraian terhadap bahan baku biji kakao yang digunakan.

Timbulnya rasa caramel pada produk cokelat disebabkan karena selama proses 
pemanasan terjadi reaksi antara gugus asam amino, peptide, atau protein dengan gugus hidroksil glikosid atau melanoidin. Reaksi ini dikenal dengan reaksi Maillard. Menurut Winarno (1992), reaksi Maillard adalah reaksi antara karbohidrat, khususnya gula pereduksi dengan gugus amina primer.

\section{Sweetness (Citarasa manis) Creamy (citarasa Cream)}

Hasil penilaian terhadap citarasa manis (sweetness) cokleta F1 adalah 6,20 dan F2 adalah 6,95 yang berarti Moderately Strong - strong.Pada penelitian ini persentase penambahan gula adalah sama pada cokelat F1 dan F2. Namun dari uji citarasa manis mempunyai nilai yang agak berbeda. Nilai citarasa manis pada cokelat F2 lebih tinggi disbanding F1 diduga disebabkan nib kakao yang digunakan disangrai dengan suhu yang berbeda. Tingginya suhu sangrai pada F2 menyebabkan asam-asam yang ada pada biji kakao akan lebih banyak menguap, sehingga rasa manis akan lebih tajam atau tinggi pada cokelat F2 dibanding dengan F1 .

Rasa manis adalah sifat rasa yang mempengaruhi citarasa keseluruhan cokelat. Rasa manis ini terutama diperoleh dari penambahan padatan gula dalam proses formulasinya. Beberapa asam amino bebas seperti glisin dan alanine serta beberapa peptida juga memberikan rasa manis. Namun, bila dibandingkan rasa manis yang berasal dari padatan gula, konstribusi asamasam amino tersebut sangat kecil. Arti penting asam-asam amino dan gula dalam biji kakao sangat besar dalam pembentukan komponen citarasa, terutama selama penyngraian.Konsentrasi asam amino dan gula akan menurun secara nyata selama proses tersebut, yakni sejalan dengan peningkatan jumlah komponen citarasa (Misnawi dan Jinap, 2008).

Hasil penilaian terhadap citarasa creamy cokelat $\mathrm{F} 1$ adalah 6,35 dan $\mathrm{F} 2$ adalah 6,70 yang berarti Moderately Strong - strong yang berarti citaras creamy agak kuat sampai kuat. Citarasa creamy dari cokelat F2 lebih tinggi dari cokelat F1.Hal ini diduga bahwa perpaduan antara rasa cokelat yang tajam dengan tekstur yang lembut menghasilkan citarasa creamy yang lebih tinggi.

Hasil pengujian citarasa secara keseluruhan diperoleh bahwa cokelat F1 penerimaan panelis secara umum adalah mempunyai citarasa aroma dan flavor yang bagus (good) dan cenderung asam,, sedangkan F2 mempunyai citarasa aroma dan flavor yang sangat bagus (very good) . Hal ini disebabkan biji kakao yang digunakan adalah biji kakao fermentasi (full fermented) dan pada cokelat F2 disangrai pada suhu $120^{\circ} \mathrm{C}$.

\section{Citarasa Asam (Acidity)}

Hasil penilaian organoleptic terhadap cita rasa asam cokelat $\mathrm{F} 1$ adalah 5,70 (Moderately Strong) dan F2 adalah 6,15 (Moderately Strong ). Nilai citarasa asam dari cokelat F1 dan F2 masuk dsalam kategori yang sama yaitu Moderately Strong (agak kuat/agak asam). Namun dari segi nilai cokelat F2 mempunyai nilai yang lebih tinggi yang berarti bahwa citarasa asam semakin berkurang. Hal ini diduga disebabkan cokelat F2 diolah dari nib kakao hasil penyangraian suhu yang lebih tinggi dibanding F2, dimana pada proses penyangraian akan terjadi penguapan asam-asam organik yang terdapat dalam biji kakao.

Citarasa asam yang timbul pada produk cokelat disebabkan karena adanya asam yang tidak seluruhnya menguap pada saat proses pengolahan cokelat, terutama pada proses penyangraian dan concing . Senyawa asam dalam biji kakao adalah asam-asam organic yang terbagi dalam kelompok asam organic yang mudah menguap terutama asam asetat dan asam yang tidak mudah menguap termasuk didalamnya asam laktat, suksinik, malik /malat, oksalat dan tartarat (Jinap dan Zeslinda, 1995).

Citarasa asam erat kaitannya erat kaitannya dengan nilai $\mathrm{pH}$. Citarasa asam (acidity) mempunyai korelasi positif dengan komponen citarasa pahit (bitterness), brown fruit, citrus, hammy, metallic, smoky, dan scooty serta tidak mempunyai korelasi nyata dengan komponen citarasa lainnya (Yusianto, 1988 dalam Sudibyo, A dan J.Astuti, 2010). 
Kehadiran rasa asam dalam jumlah sedikit akan menyumbang pada keseimbangan citarasa produk., tetapi pada jumlah yang lebih besar rasa asam diterima sebagai cacat citarasa. Asam asetat dan asam laktat yang terbentuk selama fermentasi biji kakao adalah komponen yang ditengarai sebagai penyebab cacat citarasa permen cokelat, berupa rasa asam yang menyengat dan tidak disukai (Jinap, 1964 dalam Misnawi , 2006).

Asam laktat adalah asam yang tidak mudah menguap (non volatile) dan hanya $10 \%$ dari konsentrasi yang ada dapat diuapkan selama penyangraian (Jinap dan Dimick, 1991).Asam oksalat adalah asam yang konsentrasinya cukup tinggi tetapi kecil pengaruhnya terhadap rasa asam dan citarasa keseluruhan cokelat (Jinap dan Zeslinda, 1995).

Citarasa asam, pahit dan sepat pada cokelat yang dihasilkan berasal dari biji kakao yang digunakan sebagai bahan baku . Timbulnya sedikit rasa asam , pahit dan sepat akan menyumbang pada keseimbangan citarasa cokelat, tetapi dalam jumlah yang lebih besar diterima sebagai cacat citarasa.

\section{Bitter (citarasa pahit)}

Hasil penilaian panelis terhadap citarasa pahit terhadap cokelat F1 adalah 5,75 dan Cokelat $F 2$ adalah 6,00 yang berarti Moderately Strong (agak kuat).

Rasa pahit adalah citarasa khas lain yang alami yang bisa dikecap dari cokelat. Rasa tersebut berasal dari komponenkomponen alkaloid seperti theobromin dan caffeine, komponen fenolic, pirazin, beberapa peptide, dan asam amino bebas. Rasa pahit cokelat seringkali rancu dengan rasa sepat , karena sebagian orang tidak sepenuhnya mengerti sifat-sifat perbedaan antara antara kedua rasa tersebut. Terlebih lagi tannin atau polifenol dalam cokelat sebagai komponen yang banyak bertanggungjawab terhadap rasa sepat, juga menghasilkan rasa pahit (Misnawi dan Jinap, 2008).

Clifford (1985) dalam Misnawi dan Jinap (2008) , menegaskan bahwa theobromine menampakkan rasa pahit metallic yang tidak langsung dirasakan di permukaan lidah dan bersifat stabil, sedangkan rasa pahit cokelat lebih cepat terasa dan menghilang di permukaan lidah dengan cepat. Rasa pahit cokelat dapat dirasakan di seluruh rongga mulut, sedangkan rasa pahit theobromine hanya terasa di bagian pangkal lidah. Terdapat korelasi positif yang nyata antara total polifenol dalam pasta cokelat dan tingkat kepahitannya .Timbulnya rasa pahit pada cokelat disebabkan oleh adanya theobromin, polifenol, dan flavoid dalam biji kakao (Afriansyah, 2005).

Rasa pahit cokelat dapat dirasakan diseluruh rongga mulut, sedangkan rasa pahit theobromine hanya terasa di bagian pangkal lidah. Terdapat korelasi positif yang nyata antara total polifenol di dalam pasta cokelat dan tingkat kepahitannnya (Misnawi dan Jinap, 2008).

\section{Astringency (citarasa Sepat)}

Hasil penilaian panelis terhadap citarasa sepat (astringency) terhadap cokelat F1 adalah 5,40 dan F2 adalah 4,80 yang berarti Moderately weak ( agak lemah) - Moderately Strong (agak kuat). Hal ini disebabkan cokelat F1 mengandung polifenol yang lebih tinggi yaitu $5,36 \%$ dan F2 4,83 \% (Tabel 2). Menurut Clifford (1985) dalam Misnawi dan Jinap (2008), rasa sepat cokelat meningkat seiring dengan peningkatan derajat polimerisasi polifenol yang dikandungnya.

Rasa sepat yang menonjol merupakan salah satu cacat serius yang pada cokelat yang disebabkan karena biji tidak terfermentasi. Rasa ini sangat menimbulkan rasa kurang nyaman karena mengganggu saraf di lidah yang seolah-olah menyengat dan menimbulkan rasa kering. Hal ini terjadi karena polifenol yang berlebihan pada cokelat berinteraksi dengan protein kaya prolin di air liur dan mengendapkannya (Misnawi dan Jinap, 2008).

Citarasa sepat yang timbul pada cokelat disebabkan oleh kandungan antosianin yang sebagian terurai selama proses fermentasi berlangsung karena masuknya asam pada keping biji. 


\section{Preference (penampakan)dan Texture (Kehalusan)}

Hasil penilaian panelis terhadap" penampakan" (Preference) terhadap cokelat untuk cokelat F1 adalah 6,00 dan Cokelat F2 adalah 6,55 yang berarti pada taraf Moderately Strong (penampakan cokelat agak kuat) - strong (penampakan kuat). Hal ini disebabkan proses conching dilakukan dengan menggunakan alat conching dan dengan waktu conching yang sama sehingga didapatkan tekstur cokelat yang sama pula.

Penghalusan (refening) dan koncing (conching) merupakan proses yang sangat berpengaruh terhadap citarasa cokelat. Demikian juga proses tempering menentukan tekstur cokelat.

Penghalusan sangat diperlukan untuk menghasilkan tekstur produk cokelat dan kelinciran (smoothness) cokelat saat dimakan. Melalui penghalusan yang baik, fraksi-fraksi padat dalam cokelat akan menyebar rata dalam fraksi cair (lemak) dan potensi aroma, serta citarasa dan warna khas cokelat tertampakkan (Misnawi dan Jinap, 2008).

\section{SIMPULAN}

Dari hasil penelitian dapat disimpulkan bahwa cokelat yang diolah dari biji kakao fermentasi yang disangrai dengan suhu 40 ${ }^{\circ} \mathrm{C}$ mengandung polifenol $5,36 \%$ dengan karakteristik mutu kadar air air 2,03\%, kadar protein $11,15 \%$, kadar lemak $48,67 \%$.

Cokelat yang diolah dari biji kakao fermentasi yang disangrai dengan suhu $120{ }^{\circ} \mathrm{C}$ mempunyai karakteristik mutu mengandung polifenol 4, $83 \%$, kadar air $1,43 \%$, kadar protein 8,84 \%, kadar lemak $53,39 \%$.

Dari segi citarasa secara keseluruhan diperoleh bahwa penerimaan panelis secara umum terhadap cokelat F1 adalah mempunyai citarasa aroma dan flavor yang bagus (good) dan cenderung asam,, sedangkan F2 mempunyai citarasa aroma dan flavor yang sangat bagus (very good) .

\section{DAFTAR PUSTAKA}

1. Afriansyah,N. 2005.Cokelat Sarat Antioksidan Penyehat Jantung . Puslitbang Gizi dan Makanan , Departemen Kesehatan dalam Kompas, Rabu 3 Maret 2005.

2. Anonim. 2012. Bagaimana Cokelat Dapat Membuat Anda Cepat Menurunkan Berat Badan. http://id.hicow.com/coklat/ jenis_cokelat/kesehatan_1220741.html. Diakses 26 Januari 2012.

3. Anonim , 2012. Kenali manfaat dan Bahaya Cokelat bagi Kesehatan. http://febrinavivin-xi-ips4-17.blogspot. com/2011/11/kenali-manfaat-danbahaya-cokelat-bagihtml (diakses 1901-2012).

4. Beckeett, S.T. 2000. The Science of Chocolate, RSC Paper backs, Published by The Royal Society of Chemistry, Thomas Graham House, Science Park, Hilton Road Cambridge.

5. Beckett, S.T. 2009. Industrial Chocolate Manufacture And Use, Fourth Edition. Blackwell Ltd.

6. Bernaert,Herwig,2007.Fermentation, How does it effect the Polyphenols? WCF Amsterdam,http://www. worldcocoafoundation.org/// About/documents/Benneart/ Fermentationpdf(diakses 02-04-2008).

7. Brito, D., Edy Sousa, 2004. Use of Proteolytic Enzyme in Coco (Theobroma cacao L) Processing, Brazilian Archives of Biology and Technology International Journal vol. 47 No. 4, Agustus 2004. ISSN 1516-8913.

8. Jinap,S. dan A. Zeslinda (1995). Influence of organic acids on flavor perception of Malaysian dan Ghanian cocoa beans. Journal of Food Science dan Teknology 32, 153 - 155.

9. Jinap, S; H. Siti Mordingah dan M.G. Norsiati (1994). Formation of methylphyrazine during cocoa beans fermentation. Pertanika, 17, 27, 32.

10. Jinap,S. dan P.S. Dimick (1991). Effect of roasting on acidic characteristics of coco beans. Journal of the Science of Food Agriculture, 54. 
11. Khomsan, 2003.Pangan dan Gizi Untuk Kesehatan. PT. Rajagrafindo, Jakarta.

12. Klahors, Suanne, 2005. From Cocoa to Cocoa , Food Product Design Ingridient Insight, http://www.foodproductdesign. com/archives/2005/0715INI.htmI (diakses 27-03-2006).

13. Misnawi dan Jinap, S. 2008.Citarasa , Tekstur, dan Warna Cokelat dalam buku Panduan Lengkap KAKAO, Penerbit : Penebar Swadaya, Jakarta.

14. Misnawi, 2005.Peranan Pengolahan Terhadap Pembentukan Citarasa Cokelat, Warta Pusat Penelitian Kopi dan Kakao Indonesia, Vol. 21 No. 3. Pusat Penelitian Kopi dan Kakao Indonesia , Jember.

15. Misnawi, Susijahadi, Jinap,S. Teguh Wahyudi, Novrita Putriani, 2006. Pengaruh Konsentrasi Alkali dan Suhu Koncing terhadap Citarasa, Kekerasan, dan Warna Permen Cokelat, Pelita Perkebunan, Vol. 22 Agustus 2006, Pusat Kopi dan Kakao, Indonesia.

16. Minifie, 1999.Chocolate, Cocoa and Convectionery, Science and Technology AVI, Westport, Connecticut.

17. Mulato, S., S.Widyatomo, Misnawi, E.Suharyanto, 2005.Pengolahan Produk Primer dan Sekunder Kakao. Pusat Penelitian Kopi Dan Kakao Indonesia, Jember.

18. Ramlah, S.2014.Pengaruh Suhu Penyangraian Terhadap Mutu Cokelat Sebagai Makanan Kesehatan Penurun Kadar Kolesterol Darah. Jurnal Industri Hasil Perkebunan. Volume 9 No. 2. Desember 2014.

19. Reineccius,G.A., P.G. Keeney dan W.Weisberger, 1994. Factors affecting the concentration of pyrazines in cocoa beans. Journal of Agricultural and Food Chemistry 20.
20. Ross, Jessica. 2000. Cocoa and Chocolate as Functional Foods, Journal of Medical Food, Vol.3. No. 2. 2000.

21. Sudibyo, A dan J.Astuti, 2010. Mempelajari Karakteristik Kimia dan Citarasa Cokelat Formulasi dari Biji Kakao yang Berasal Dari Berbagai Daerah Penghasil Kakao di Indonesia. Jurnal Industri Hasil Perkebunan, Vol. 5 (1).

22. Suprapti, et al. 2011.Pembuatan Makanan Kesehatan Dari Pasta Cokelat Non Fermentasi Kaya Polifenol. Laporan Penelitian Balai Besar Industri Hasil Perkebunan , Badan Pengkajian Kebijakan Iklim Dan Mutu Industri, Kementerian Perindustrian .

23. Suprapti, 2013. Pengolahan Biji Kakao Menjadi Pasta Cokelat Sebagai Makanan Kesehatan Penurun Bobot Badan Dan Kolesterol Darah. Jurnal Riset Teknologi Industri. Vol.7 no. 13 Juni 2013.

24. Star, Michael and Other, E \& OE, 2006. HealthyChocolate ? Cocoa is The Best Antioxidant Food.http://www. astrologyzine.com/healthy .chocolates. Diakses 11 April 2006.

25. Thomas,Berberan, FA., Elena Cienfuegos J, Alicia Marin, Begona, 2007.

26. Winarno,FG. 1992. Kimia Pangan dan Gizi. PT. Gramedia Pustaka, Jakarta.

27. Winarno, FG. 1980. Pengantar Teknologi Pangan. Penerbit PT.Gramedia Pustaka, Jakarta. 